1 Hamburg University of Applied Sciences, Hamburg, Germany

Ralf.Reintjes@haw-hamburg.de Cite this as: BMJ 2020;369:m2522 http://dx.doi.org/10.1136/bmj.m2522 Published: 25 June 2020

\title{
Lessons in contact tracing from Germany
}

\section{Germany built on existing local infrastructure to get ahead of the covid-19 pandemic Ralf Reintjes professor of epidemiology and public health surveillance}

The pandemic situation in Germany is often compared favourably with that in other European countries, particularly the UK. According to the World Health Organization, the rate of infection reported in Germany by 23 June was almost half the rate reported in the UK (230 cases/100 ooo population $v$ 451/100 ooo), and the reported mortality from covid-19 was a sixth of that in the UK (10.7/100 000 v63.2/100 000).

Care must be taken when comparing data from different countries, ${ }^{1}$ and various reasons may explain the observed differences. ${ }^{2}$ But from a public health perspective, experience with $\mathrm{SARS}^{3}$ suggests that Germany's intensive system of testing, contact tracing, and quarantine were critical to successful control of the outbreak, especially given the role of super spreading events that seem to shape the current epidemic in Germany, with the most recent ones in meat plants. ${ }^{3}$

Germany is organised into 16 federal states, which hold responsibility for health. Outbreak investigation and management, including contact tracing, is the responsibility of local health authorities at city or county level, with support from state health departments and the national institute for public health, the Robert Koch Institute, when necessary. ${ }^{4}$

\section{Local public health}

Covid-19 became a notifiable disease in Germany on 1 February 2020, ${ }^{5}$ earlier than in the UK. ${ }^{6}$ Disease notification requires clinicians by law to notify suspected cases to the public health authorities. Laboratories are similarly required to notify the authorities of tests for notifiable diseases. In Germany, disease notifications from clinicians and laboratories primarily go to local authorities, where most of the practical work in infection control takes place.

The first covid-19 outbreak occurred in Bavaria in late January, and it was rapidly controlled with testing, contact tracing, isolation, and quarantine. However, new outbreaks seeded from other sources began to spread, ${ }^{7}$ and the need to break the chain of transmission with nationwide measures (lockdown) became evident. At the same time local public health services were mobilised and revitalised. In April both federal and state governments agreed to provide additional investment to strengthen local public health authorities. ${ }^{8}$ Civil servants were redeployed to public health from elsewhere and extra staff employed to support local contact tracing. Germany built on existing infrastructure and experience from the outset, unlike England, where local public health departments were overlooked in favour of a centralised system run by outsourced companies.
Later, as population restrictions were being lifted, chancellor Angela Merkel and the prime ministers of the federal states agreed that local authorities should have five contact tracers for every 20000 citizens. ${ }^{9}$ Inexperience of new staff members was overcome by embedding them in experienced organisational structures, helping to limit the difficulties reported in England. ${ }^{10}$

\section{Local thresholds}

Expanded capacity for contact tracing underpinned decisions on 6 May to reopen society in a stepwise fashion. States agreed that population infection control measures such as school closures or even "lockdowns" would be reactivated locally if infection rates reached a threshold of 35-50 cases per 100000 inhabitants a week in a region. ${ }^{11}$ Overall, the flexibility of local infectious disease control with centralised coordination and support seems to be effective so far, and stands in contrast to the more centralised and privatised approach taken in the UK.

Like many other countries, Germany deployed technological solutions, including an anonymised and decentralised contact tracing app that was launched on 16 June. Concerns over privacy led to a reversal of previous plans to collect data more centrally and thus to a delay. Data protection rights are taken seriously in Germany, and data collected by the app is held only on individual phones, with no central database. Public health experts, however, have limited expectations: in a recent survey, $38 \%$ of responding public health departments had doubts about the added value of a contact tracing app or considered it potentially problematic. ${ }^{12}$

Although Germany's lockdown was less intense and shorter than in some other European countries, including the UK, early implementation, in combination with widespread testing, contact tracing, and quarantine, have been successful in reducing the incidence of covid-19 and both covid-19 specific and excess deaths. So far, the epidemic has remained stable through stepwise relaxation of control measures, although recent outbreaks in several meat plants (one including more than 1000 cases) are obvious challenges to the system. Strong measures, including a regional lockdown, have been taken to control these outbreaks.

Timely data on suspected cases is now vital, along with rapid testing, fast turnaround times for results, and comprehensive contact tracing. National testing guidelines are adjusted regularly in response to developments. ${ }^{13}$ A second wave remains a risk, and the authorities continue to monitor the situation closely. ${ }^{14}$ With no vaccine, and no specific antiviral 
treatments, preventing transmission through public health measures is now more important than ever. ${ }^{15}$

Competing interests: I have read and understood BMJ policy on declaration of interests and have no interests to declare.

Provenance and peer review: Commissioned; not externally peer reviewed.

1 Reintjes R. Variation matters: epidemiological surveillance in Europe. J Health Polit Policy Law 2012;37:955-65. doi: 10.1215/03616878-1813790 pmid: 22899836

2 Krumkamp R, Mounier-Jack S, Ahmad A, Reintjes R, Coker R. Evaluating health systems' preparedness for emerging infectious diseases: a novel conceptual and analytic framework. Health Policy 2010;98:91-7. doi: 10.1016/.j.healthpol.2010.06.004 pmid: 20638149

3 Ahmad A, Krumkamp R, Reintjes R. Controlling SARS: a review on China's response compared with other SARS-affected countries. Trop Med Int Health 2009;14(Suppl 1):36-45. doi: 10.1111/j.1365-3156.2008.02146.x pmid: 19508440

4 Hawker J, Bergg N, Reintjes R, etal. Communicable disease control and health protection handbook. 4th ed. Wiley-Blackwells, 2019: 414-5.doi: 10.1002/9781119328070.

5 Bundesministerium der Justiz und für Verbraucherschutz. Verordnung über die Ausdehnung der Meldepflicht nach $\S 6$ Absatz 1 Satz 1 Nummer 1 und $\S 7$ Absatz 1 Satz 1 des Infektionsschutzgesetzes auf Infektionen mit dem erstmals im Dezember 2019 in Wuhan/Volksrepublik China aufgetretenen neuartigen Coronavirus. 2020; https://www.gesetzeim-internet.de/coronavmeldev/_1.html

6 UK Government. Coronavirus (COVID-19) listed as a notifiable disease. 5 Mar 2020; https://www.gov.uk/government/news/coronavirus-covid-19-listed-as-a-notifiable-disease

7 Böhmer MM, Buchholz U, Corman VM, etal. Investigation of a COVID-19 outbreak in Germany resulting from a single travel-associated primary case: a case series. Lancet Infect Dis 2020: doi: 10.1016/S1473-3099(20)30314-5. pmid: 32422201

8 Streit um Unterstützung des Bundes für Öffentlichen Gesundheitsdienst. Deutsches Ärzteblatt 2020 May 11. https://www.aerzteblatt.de/nachrichten/112740/Streit-um-Unterstuetzung-desBundes-fuer-Oeffentlichen-Gesundheitsdienst

9 Wilp C. Merkel appelliert eindringlich: "Wir sind noch nicht übern Berg!” RTL 2020 Apr 20. https://www.rtl.de/cms/merkel-appelliert-eindringlich-wir-sind-noch-nicht-uebern-berg4526788.html

10 Mueller B, Bradley J. England's “world beating” system to track the virus is anything but. New York Times 2020 Jun 17. https://www.nytimes.com/2020/06/17/world/europe/uk-contact-tracingcoronavirus.html?auth=linked-google

11 Kempmann A, Horn C, Baars C, et al. Corona-tracing: Gesundheitsämtern fehlt Personal. NDR Info 2020 May 14. https://www.ndr.de/nachrichten/info/Zu-wenig-Personal-in-vielen-Gesundheitsaemtern,gesundheitsaemter100.html

12 Fiedler T. Recherchen zeigen "sehr große Löcher" im Netz der Kontaktverfolgung durch die Gesundheitsämter in Deutschland. Business Insider 2020 May 11. https://www.businessinsider.de/wissenschaft/recherchen-zeigen-sehr-grosse-loecher-im-netz-der-kontaktverfolgung-durchdie-375-gesundheitsaemter-in-deutschland/

13 Robert Koch Institut. Hinweise zur Testung von Patienten auf Infektion mit dem neuartigen Coronavirus SARS-CoV-2.2 Jun 2020. https://www.rki.de/DE/Content/InfAZ/N/Neuartiges_Coronavirus/Vorl_Testung_nCoV.html

14 Wise J. Covid-19: risk of second wave is very real, say researchers. BMJ2020;369:m2294. doi: 10.1136/bmj.m2294 pmid: 32518177

15 Reintjes R, Das E, Klemm C, Richardus JH, Keßler V, Ahmad A. "Pandemic public health paradox": time series analysis of the 2009/10 influenza A/H1N1 epidemiology, media attention, risk perception and public reactions in 5 European countries. PLoS One 2016;11:. doi: 10.1371/journal.pone.0151258 pmid: 26982071

This article is made freely available for use in accordance with BMJ's website terms and conditions for the duration of the covid-19 pandemic or until otherwise determined by BMJ. You may use, download and print the article for any lawful, non-commercial purpose (including text and data mining) provided that all copyright notices and trade marks are retained. 